Fas媒介アポトーシスに関する解析結果をふまえた珪肺症症例の臨木パラメーターの評価 ○大柣㴊已1，市原清志 2 ，友国 晶子1，坂口治子1，草加勝康 3 ，植木 絢子1 (1川崎医科大学街生学，2検查診断学，3草加病院内科)

[目的]珠肺症での免疫異常は従来より知られており自己抗体の出現や強皮症・SLEなどの全身 性自己免疫疾患の合併も経験されている。我々は従来上り珪肺症症例での血清可溶性 Fas (SFas)，Fas ligand (SFasL)，リンパ球膜表面Fas (mFas)，末梢血単核球での可溶性Fas 発現 の膜型Fas発現に対する相对比 (s/mFasExR)を検討してきた。今は，これらのFas媒介アポトー シスの臨床パラメーターとしての評価を検討した。[方法]主治医よりのインフォームドコンセント を得た自己免疫症状や悪性腫演を伴わない58例の珪肺症において曝露年数(年)，呼吸不全 (俥度 [1]，中等度 [2]，高度 [3])，PR(レ線的分類) $\left(0,1 ， 2 ， 3 ， 4 \mathrm{~A}, 4 \mathrm{~B}, 4 \mathrm{C} の 7\right.$ 段階)， $\mathrm{PO}_{2}$ (torr) ,

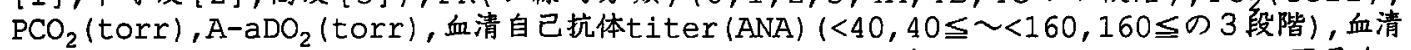
$\mathrm{IgG}$ 值 (mg/dl), mFas (o) , sFas (ng/ml), sFasL (ng/ml)，及びs/mFasExR(ratio)の12因子を，

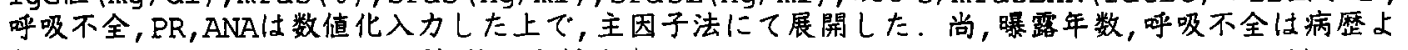
り， $\mathrm{PO}_{2} ， \mathrm{PCO}_{2}, \mathrm{~A}-\mathrm{aDO} \mathrm{DO}_{2}$ 血液ガス分析より，ANA，SFas，SFasLはELISAにて，mFasはflow cytometryにて，そしてs/mFasExRはsemiquantitative multiplex RT-PCR法にて解析した結 果を用いた。[結果] $2 つ$ つ方向性を示す因子群が抽出され，因子 $1\left(\mathrm{PO}_{2}, \mathrm{~A}-\mathrm{aDO}_{2}\right.$ ，呼吸不全が強く寄 与， $\mathrm{PCO}_{2}$ ，曝露年数が中等度に寄与す万) は肺病変因子，因子 2 ( I g G，s Easが強 〈,ANA，SFasL，s/mFasExRが中等度に奇与する)は免疫学的因子と推定された。また，各症例での 両因子の分布を検討すると，一部，病態のべクトルが免疫学的因子側にのみ強く異常を呈する症例 が認められた。[考察]Fas媒介アポトーシス関連の臨床检体での測定值は免疫学的パラメーターと しても有用であることが示唆された。また個人の素因によっては免疫異常側へ強くシフトする病 態を有する症例も認めらたことは，拄酸化合物惹起免疫異常の解析に際して興味深いと思われた。

\title{
W 16-2
}

MPO-ANCA関連血管炎の臨床的ならびに病理学的検討

○坂入京子、福島史哉、武田 昭、平田博国、白鳥共二、三好祐顕、船越友恵、 前澤玲華、井上 明、岡田壮令、芹澤良幹、福島康次、沼尾利郎、福田 健 (獨協医科大学 呼吸器・アレルギー内科)

[目的] MPO-ANCA関連血管炎の自験 6 例について、その臨床病態の特徵を検討した。 [対象] MPO-ANCA陽性 $(65-940 \mathrm{EU} / \mathrm{ml})$ で血管炎症状を呈した 6 例の内訳は、男性 2 例、女 性 4 例、年歯 $20-75$ 歳(平均56歳)。RAの合併 1 例、甲状腺機能六進症の合併 2 例が含まれた。 [結果]発症の誘因として、甲状腺機能六進症の 2 例では、プロピルチオウラシル(PTU)、ある いはメルカゾール(MMI)の関与が疑われた。臨床症状では、全例に発熱、炎症反応を認めた他、 腎障害 3 例、皮疹（紅斑、潰場） 2 例、未梢神経障害 2 例、肺胞出血、間質性肺炎、聴力障害、 葡萄膜炎、心伝導系障害、足壊瘨が見られた。組織所見では、3例に腎生検を行ない、半月体 形成性腎炎、壊死性血管炎、硬化性糸球体腎炎を認め、1 例に肺生検を施行しへモジデローシ スを認めた。2 例に皮膚生検を施行。治療については、薬剤性が疑われる 2 例のうち、1 例は PTU中止のみで改善、1 例はMMI中止およびPSL40mg開始によりMPO-ANCA陰性化と臨床 症状の改善を認めた。他の 4 例では、PSL20-60mgあるいはステロイドパルス療法、シクロ フォスファミド25-100mg投与を行ない、いずれもMPO-ANCAは陰性化したが、1例は人 工透析導入を要し、また、1 例は感染症にて死亡している。

[結語]自験例での検討ではあるが、MPO-ANCA関連血管炎における臨床症状および臟器障害 の多様性が浮かび上がった。また、発症における薬凨関与の可能性も注目された。 


\section{W 16-3}

多発性筋炎における副婜皮質ステロイド治療とクレアチンキナーゼ值

○岩本雅弘、平田大介、佐藤英智、長嶋孝夫、奈良浩之、金子尚子、 上村健、岡崎仁昭、益山純一、吉尾卓、狩野庄吾、篊田清次

（自治医科大学アレルギー膠原病科）

[目的]当科で治療された多発性筋炎患者の副腎皮質ステロイド治療反応性をクレ アチンキナーゼ (CK) 值を指標に調ぶること

[方法]当科で治療された多発性筋炎患者の診療録を調べ、CK 值を片対数グラフ用 紙にプロットする。

〔結果〕 24 症例で 26 回の治療経過を解析した。経ロステロイド剤（ス剤）のみで 17 回治療された。経ロス郕だけでは効果不十分と判定され、ステロイドパルス療法 が 2 回施行され、免没抑制剂が 3 回使用された。その他の理由で免疫抑制剤が 3 回併 用された。また、手術のため、1 例で経ロス剤が急速に減量された。経口ス剤のみで 治療された症例は C K 值を片対数グラフ用紙にプロットすると直線状に分布した。ま た、ス郕抵抗性のため、C K 值が直線上に分布しなかった症例もステロイドパルス療 法または免疫抑制剂を併用後は片対数グラフ上で、C K 值は直線的に減少した。直線 の傾きは症例により異なり、入院時のC K 值の高低とは関係なかった。

[結語] C K 值を片対数グラフ上にプロットすることで、経口ス剤に対主る反応性を 評価できる。

\section{W 16-4}

糖尿病性腎症の進展過程におけ補体系の活性化

○藤田 宜是, 大井 洋之, 里村 厚司, 日高 睦子, 大沢 勲, 遠藤 守人, 上松瀬 勝男 (日本大学医学部第 2 内科)

[目的］原発性腎疾患では腎障害の発症進展過程に補体系の関与が知られている。糖尿 病でも病態に自己免疫機転の関与が知られており, モデル動物の腎系球体には補体の沈着 が報告されている。糖尿病性腎症において補体系が腎症の発症進展に如何なる役割を担う ているか明らかにするために以下の検討をおこなった。 [方法] NIDDM患者 55 例と健常 者 21 例を対象に血中の補体成分 (C3, C4, Factor B) をSRID法で, 補体分解産物（iC3b, C4 $\mathrm{d}, \mathrm{Bb}$ )をELISA法で測定し, 分解率を算出し補体活性化の指標とした。また, NIDDMのモ デルとされる OLETFラット（5５週齢）の障害された糸球体切片にモルモット血清を添加 し $37^{\circ} \mathrm{C}$ で 30 分加温後 FITC 標識抗ラットC 3 を用いて補体の沈着の有無を検討した。

[結果] 健常者では C3: $112 \pm 21 \%$ normal, $i \mathrm{C} 3 \mathrm{~b}: 5.51 \pm 2.77 \mu \mathrm{g} / \mathrm{ml}, \mathrm{C} 4: 106 \pm 19 \%$ normal, C4d: $21.8 \pm 7.71 \mu \mathrm{g} / \mathrm{ml}$, Factor B: $102 \pm 17 \%$ normal, Bb: $0.09 \pm 0.41 \mu \mathrm{g} / \mathrm{ml}$ であったが, NIDDMでは C3: $152 \pm 47 \%$ normal, $i \mathrm{C} 3 \mathrm{~b}: 30.6 \pm 21.0 \mu \mathrm{g} / \mathrm{ml}, \mathrm{C} 4: 171 \pm 62 \%$ normal, C4d: 41.9 $\pm 16.6 \mu \mathrm{g} / \mathrm{ml}$, Factor B: $162 \pm 62 \%$ normal, Bb: $2.55 \pm 6.23 \mu \mathrm{g} / \mathrm{ml}$ と有意に増加していた。 OLETFラット腎切片とモルモット血清との反応では糸球体にモルモットC 3 の沈着を認め た。この沈着はEDTA 添加時には認められなかった。［結語］糖尿病性腎症では障害され た系球体を反応の場とする補体系の活性化がおこっている可能性が示唆された。 


\section{W 16-5}

結合織疾患に扔ける凝固線溶系異常の解析（第2 報）

○加藤賢一、吉田秀雄、深谷修作、大島久二、吉田俊治、鳥飼勝隆

(藤田保健衛生大学 感染症・リウマチ内科)

（目的）結合織疾患(CTD)の凝固線溶異常の臨床的意義を明らかにする。

(対象及び方法) CTD患者164名(SLE51名、RA38名、PM/DM17名、SSc10名、MRA9 名、壞死性血管炎12名、その他27名)を対象とした。各種CTDにおける凝固線溶異常の 型、疾患活動性との関連、炎症性サイトカインとの関連を検討した。

(結果) 凝固線溶異常は、RA血管炎型:SFDP、Fibともに高値。SLE型：sFDP正常一高 値、Fib正常～軽度高値。その他型：sFDP非高値、Fib正常～高値の3型に分類しえた。 sFDPは、抗DNA抗体価・補体値が明らかな異常を示さない活動期SLEにおいて著明高 值を示し、ステロイド治療後速やかに低下した。SLEとRAにおいて、IL-1 $\beta$ はそれぞ れ $16.6 \pm 35.5 \mathrm{pg} / \mathrm{ml} 、 29.5 \pm 20.8 \mathrm{pg} / \mathrm{ml} 、 \mathrm{IL}-2$ は $\pm 0 \mathrm{pg} / \mathrm{ml} 、 0.83 \pm 2.9 \mathrm{pg} / \mathrm{ml} 、 \mathrm{IL}-6$ は $11.1 \pm$ $7.7 \mathrm{pg} / \mathrm{ml} 、 13.4 \pm 11.1 \mathrm{pg} / \mathrm{ml}$ で、両疾患間に差は認めなかった。活動期と非活動期を比較 しても同様であったが、IL-1 $\beta$ と sFDPはSLEにおいて有意な正相関 $(\mathrm{p}<0.01)$ を認めた。

（結論）1：CTDの凝固線溶異常は、SLE群、RA・血管炎群、その他群の 3 群にわかれ た。2:SLEにおいてSFDPはIL-1 $\beta$ と相関し、さらに、抗DNA抗体価・補体值が明らか な異常を示さない活動期SLEにおいて著明高值を示し、ステロイド治療後速やかに低下 したことから、SFDPがSLEの疾患活動性の指標となっている可能性が示唆された。

\section{W 16-6}

慢性関節リウマチに合併する細気道病変の踟床的意義と治療法に関する研究 O加勢千容 ${ }^{1}$, 山田秀裕 ${ }^{1}$, 山前正臣 ${ }^{1}$, 柴田朋彦 ${ }^{1}$, 山崎宜興 ${ }^{1}$, 大久保道子 ${ }^{1}$, 浜 信昭 ${ }^{1}$, 市川陽 ${ }^{1}$, 笹下 薰 $^{2}$, 中島康雄 ${ }^{2}$

('聖マリアンナ医大リウマチ・膠原病・アレルギー内科, 2 同放射線科)

[目的] 慢性関節リウマチ(RA)に合併する細気道病変の臨床像を解析し，RA活動性と の関連を明らかにすること，及びその治療法を確立することを目的とした。

[方法] 過去 8 年間に当科を受診したRA患者 300 例のうち, 呼吸器症状のあるものに胸部 単純 X線, 高分解能CT及び肺機能検查を施行した。感染症, 腫瘄, 薬剤性は除いた。 [結果] 細気道病変は19例 $(5.8 \%)$, 間質性肺炎は 41 例( $12.5 \%)$ に認められ, 間質性肺炎 が男性に多いのに比べ細気道病変は女性に多かった。細気道病変の9例は胸部単純 X線で 異常が認められなかった。細気道病変のある患者は, 間質性肺炎の患者や肺病変のない患 者と比べ，RA発症10年以内にstage 3 以上の関節破壊に至る率が有意に高加た。細気 道病変による症状の增悪に伴って活動性滑膜炎数とリウマトイド因子の上昇する例が多 かった。15例の細気道病変に対し, クラリスロマイシン $200 \mathrm{mg}$ を6ケ月以上投与した結 果, 呼吸器症状・肺機能の改善が 7 例にみられたのみならず, RA活動性の改善が8例にみ られた。クラリスロマイシンに不応2 2 例を含む4例にミノサイクリン $100 \mathrm{mg}$ が6ケ月以上 投与され, 全例が呼吸器症状とRA活動性の改善がみられた。

[結語] 細気道病変をもつRA患者は関節破壊が高度に進行するため, HRCTによる早期 発見とマクロライドヌはミノサイクリンによる治療が必要であると考えられた。 


\section{W 17-1}

$\mathrm{C} 4$ 欠損症合併強皮症の 1 例

○桶谷美香子 ${ }^{1}$, 長岡章平 ${ }^{1}$, 川口とし子 ${ }^{2}$, 山本美穂 ${ }^{2}$, 北村 創 $^{3}$

( ${ }^{1}$ 横浜南共済病院リウマチ科, ${ }^{2}$ 皮膚科, 病理)

補体第 4 成分欠損を認めた強皮症を経験したので報告する。

【炡例】76歳, 女性, 無職

【家族歴】父,レイノー現象，【既往歴】特記すべきことなし，【現病歴】50歳頃,レイ， 一現象出現。昭和 63 年 4 月, 気管支肺炎にて某病院入院(セフェム系抗生物質のフレルギ 一)。同病院皮虚科にて強皮症の診断。平成 10 年 7 月 1 日，精查加療のため当科紹介。

【臨床所見】両側前腕におよぶ皮㲊硬化, 手指短縮, 皮唐毛細血管拡張, 食道拡張などが 認められたが, 肺線維症はなかった。末血, 生化学, 尿所見では特に異常を認めなかった。 自己抗体は，抗核抗体 2560 倍 ( Sp)，抗セント口メフ抗体陽性を示し， $\mathrm{C}_{4}$ は $1.8 \mathrm{~kg} / \mathrm{d}$ と著 減していた。その他の補体蛋白は $\mathrm{C}_{1} \mathrm{q} 12.5, \mathrm{C}_{2} 1.8, \mathrm{C}_{3} 71, \mathrm{C}_{5} 11.3, \mathrm{C}_{6} 4.8, \mathrm{C}_{7} 5.6, \mathrm{C}_{8} 7.4, \mathrm{C}_{9} 6.7$ であっ た。C 4 欠損症は全身性エリテマトーデスではしばしば報告はあるが，強皮症では稀である と考えられ報告する。

\section{W 17-2}

放射線照射後に生じた手掌のSCC in situ，手背の放射線皮虏を各々契機に診断 された全身性強皮症の2例

○佐々木哲雄 ${ }^{1}$, 宮本秀明 ${ }^{2}$, 岡島光也 ${ }^{1}$

${ }^{1}$ 横浜市大皮庙科, ${ }^{2}$ 神奈川がんセンター皮㲊科

全身性強皮症 (SSc)では放射線照射による線維化が通常よりも激しく出現しやすいことが 知られている。[症例1]75歳女。初診：1997年1月23日。現病歴：20歳頃から両手に湿疹様 皮疹が生じ難治性で, 30 歳頃から放射線と紫外線の照射を的1年間受けた。その後, 照射部に 徐々に角化硬化性変化が生じ, 91年某病院皮㲊科を受診, 93年から両手掌にびらん出現, 96年 12月同科で生検後,当科に紹介された。現症：両手指手掌皮店硬化と屈曲拘縮,舌小帯短縮 を認めた。検查成績 : 抗セントロメア抗体陽性。治療経過 : 両手掌の一部に切除植皮術施 行（病理組織はSCC in situと真皮膠原線維増生）。[症例2]76歳女。初診：1997年1月7日。 現病歴：31歳頃手湿疹のため右手に2年間に計 10 回, 35 歳時 3 回放射線照射を受けた。90年か らRaynaud現象あり。96年右手背にびらんを生じ当科受診。現症：両手指皮虑硬化と右手背 皮唐萎縮と一部のびらん。検査成績：抗セントロメア抗体陽性。両肺底部線維症。治療経 過：97年2月,右手背病変切除植皮（病理組織は慢性放射線皮眉）。その後,手指硬化と屈曲 拘縮增強。[考案]本例では放射線照射がSSc誘発因子として作用した可能性とSScでは放射 線感受性が高い可能性が考えられる。両例とも1imited SScで軽症の高齢者であり,SScを疑 われず見過ごされている同様症例もあると思われ，注意が必要である。 


\section{W 17-3}

$\mathrm{p}$-ANCA陽性半月体形成性腎炎の発症が先行した強皮症の一例

○小泉隆一, 出浦洋, 田村茂生, 植木嘉衛, 塚田義人，

金井秀夫, 前澤晃, 野島美久, 成清卓二

(群馬大学第 3 内科)

症例 48 歳、女性。昭和 40 年頃より Raynaud症状が出現していた。H4年 12月発熱、喀血、 呼吸困難を主訴に入院。胸部に湿性ラ音、chestX-P上両側下肺野に肺胞除影を認め、 $\mathrm{pCC} 2$ 36.2、p02 25.8と著明な低酸素血症を認めたため、レスピレーター管理となった。また、 尿蛋白 $300 \mathrm{mg} / \mathrm{dl}$ 、尿潜血 $(3+)$ 、堅機能障害 $(\mathrm{Cr} 2.1 \mathrm{mg} / \mathrm{dl})$ を認め、p-ANCA陽性、抗核抗体 5120 倍 (speckled)、留生検ではpauci immune型の半月体形成性堅炎(CrGN)を認めた。肺胞 出血とCrGN及びにp-ANCA陽性よりmicroscopic polyangitis(MPA)と訩断。メチルプレド二 ソロン $1000 \mathrm{mg}$ による゚ルス療法と経ロシクロフォスファマイド50mg併用による治療を開始 したところ、臨床検查所見の改善が認められ平成 5 年 2 月に退院した。抗核抗体陽性なら びにRaynaud 症状を除き、この時点では他の翏原病を示唆する所見は認められなかった。 平成 10 年頃より、指尖硬化が明らかとなり舌小帯の短縮及び抗RNP 抗体陽性が認めら扎、 強皮症（SSC）の所見が顕性化した。近年、SSCの経過中にANCA陽性のCrGNの合併がみられ ることが着目されているが、本例では、皮症症状にp-ANCA陽性の血管资が先行した点、稀 な症例と考えられたので報告する。

\section{W 17-4}

硫酸ペプロマイシン使用後に発症した非定型強皮症の 1 例 浅野善英、鹿田純一郎、門野岳史、菊池かな子、玉置邦彦 (東大皮膚科)

72 歲男性。97 年 6 月、下口唇の有棘細胞癌に対し、腫瘍切除術を行い、術後化学療法 として硫酸ペプロマイシンを総量 $75 \mathrm{mg}$ 筋注した。98 年 2 月、左前腕に皮膚硬化が出現し、 3 カ月の間に、右前腕、両下腿、頸部、下腹部、腰部へと皮唐硬化が拡大した。非定型強 皮症、好酸球性筋膜炎を疑われ、98 年 6 月 11 日、当科に入院となった。入院時、強い全 身掻痒感を訴えており、背部には、線状の色素沈着がみられた。手指手背の皮膚硬化、屈 曲拘縮、指尖部虫喰様瘢痕、爪郭部出血点、舌小帯短縮および Raynaud 現象はみられな かった。血算に異常はなく、抗核抗体は陰性、CK、アルドラーゼなどの筋原性醭素は正常 で、肺線維症、食道蠕動能などの内臓病変はみられなかった。左前腕伸側の病理組織では、 真皮中層から下層の著明な膠原線維の膨化・増生と付属器の萎縮、血管周囲性の中等度の 炎症細胞浸潤がみられた。筋膜への細胞浸潤および筋膜の肥厚はみられなかった。以上よ り、自験例を非定型強皮症と診断した。発症が急速なため、ブレドニゾロン $30 \mathrm{mg} / \mathrm{day}$ 内 服による治療を開始し、2 週間後より、皮膚硬化の改善がみられた。現在、10mg/day まで 減量し、皮膚硬化は、左前腕と両足関節周囲のみとなっている。過去にブレオマイシン使 用後に生じた強皮症の報告は散見されるが、ブレオマイシンの誘導体である硫酸ペプロマ イシン使用後に生じた強皮症の報告は、我々の調べ得た限りではみられなかった。 


\section{W 17-5}

春椎旁おょび春柱管内に著明な石灰化を来した強皮症の 1 例 ○阿久津昌子、小川武彦、小川加奈、斉藤栄造 東邦大学医学部第 4 内科

症例は53 歳、女性。1983 年、Diffuse scleroderma、食道蠕動運動低下、間質性肺炎、 抗 Scl-70 抗体陽性にて強皮症と祄断され、以後外来通院中であった。1998年3月初旬より、 左股関節痛、両下肢脱力感およびしびれ感が出現し、歩行困難となったため3月19日当院 入院となる。入院時神释学的所見では、第4-5胸椎レベル以下に一致して温痛覚、振動覚お よび位直覚の低下がみられた。また徐々に下肢の筇力低下が進行し、両下肢の弛緩性麻㾝を 呈し、膀胱直腸障害を伴った。画像所見では単純 $\mathrm{X}$ 線写真上、左股関節腔の狭小化々著明な

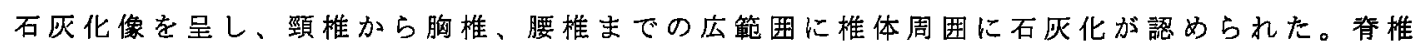
の CT 検查では同じく頸椎、胸椎おょび腰椎管に著明な石灰化を認め、第 3-7 胸椎レベルで は脊柱管内一石灭化の塊が進展し、春柱管狭䆣を呈していた。石灰化に対して diltiazemの 投与を開始、リハビリを開始した。その後、第 60 病日頃より両下肢の笳力はやや改善し、 痛覚も徐々に回復、しびれなどの自覚症状も軽快傾向となり退院となった。本例は著明な石 灰化を頸椎から胸椎、腰椎にかけて認め、胸椎レベルでは、督椎管狭窄症状を呈した。春椎 旁および尙柱管内への石灰化を来した強皮症患者の報告はごくまれである。また、その石灰 化の機序、治療法についてはいまだ確立されたものはなく、今後注目すべき病態と考えられ た。

\section{W 17-6}

Mycobacterium kansassi 感染により関節炎の増悪をきたした強皮症の一例

○岩田広香 ${ }^{1}$ 、木下牧子 ${ }^{2}$ 、隅谷護人 ${ }^{2}$ 、岩井晶子 ${ }^{3}$ 、青塚新一 ${ }^{3}$ 、平田大介 ${ }^{4}$ 鉒田清次 ${ }^{4}$

( ${ }^{1}$ 国立ガンセンター東病院内科、 ${ }^{2}$ 国立国際医療センター膠原病内科、 ${ }^{3}$ 同・臨床 免疫、 ${ }^{4}$ 自治医科大学アレルギー膠原病内科）

29 年前にレイノー現象で発症した強皮症患者(49才女性)が発熱と多発性関節炎を主訴 に入院した。経過中に、近位部皮膚硬化、手指硬化、指尖潰愓、両下肺野肺線維症、食道 蠕動低下拡張を呈した。入院時の検査所見では、血沈六進 $(109 \mathrm{~mm} / \mathrm{h}) 、 \mathrm{CRP}$ 增加 (3.2 $\mathrm{mg} / \mathrm{dl})$ 、リウマトイド因子增加 $(1410 \mathrm{IU} / \mathrm{ml})$ 、抗 U1-RNP 抗体陽性 $(>200 \mathrm{COI})$ 、抗 $\mathrm{Sm}$ 抗体陽性 (>200COI)、抗 dsDNA 抗体陽性(33COI)が認められた。胸部レントゲン写真上、 左肺尖部の空洞病変および以前からある下肺野の網状粒状影を認めた。手のレントゲン写 真では、手指末節骨の吸収、PIP・MPの破壊性・ビラン性関節炎、手関節の強直を認め た。左肺尖部の空洞病変は、喀痰培盖により Mycobacterium kansassi 感染と診断された。 INH、EB、REFによる化学療法の開始後、空洞は縮小し、関節炎の改善が認められた。 同時に、血沈、CRP、リウマトイド因子(特に IgM および IgAクラス)、抗 heat shock protein 抗体（抗 mycobacterial HSP 65 抗体、抗 human HSP 60 抗体）の抗体価も低下した。本 症例が HLA-DR4 陽性であったことより、関節炎発現の病因における molecular mimicry の関与について考案する。 


\section{W 18-1}

経過中にHeparin induced thrombocytopeniaを併発した抗SS-A抗体症候群の1例

○和田靖之、高野容子、久保政勝

（東京慈恵会医科大学小児科）

抗SS-A抗体症候群はTsokosらによって提唱された疾患概念で、抗SS-A抗体陽性を特徵とし、血 管炎、血球減少といった血液学的異常、リウマチ因子陽性や低補体血症、抗核抗体陽性などの検査 異常を呈する疾患て、腺外症状を呈するSjögren症候群、抗核抗体陰性SLE、亜急性皮膚エリテマ トーデス、新生児ループスなどを含めている。今回我々は、15年間の長期にわたり本疾患と考えら れる症例を経過観察しえた。（症例）24歳女性。10歳時に関節炎、皮疹を呈し、皮膚病理組織標本 は血管周囲にリンパ球の浸潤がみられた。その後無治療で経過観察していたが、15年間後に発熱、 関節痛が出現。以後発熱は持続し紫斑などの皮膚血管炎症状が出現、血液検査上でも沉血球減少を 呈するようになり、ステロイドパルス療法や免疫抑制剤などの治療をおこなったが抵抗性を示した 。また $99 \mathrm{mTc}$ を用いた唾液腺シンチグラフィは正常であった。症例の末梢血を用いて、血小板の膜 表面に存在するglycoprotein I bに対する抗体を測定したところ、治療に用いていたheparinの投 与期間に一致し同抗体の著明な増加がみられ、heparinによる血球減少と考えた。その後heparin の投与中止、血小板凝集抑制の目的でアスピリン、さらに新鮮凍結血漿の投与を行ったところ、解 熱し種々の検查所見の改善が得られた。(結語) 本症例の経過は、小児期にみられる非典型的な膠 原病様の病態および治療を考える上でも示唆に富む症例と考え、報告する。

\section{W 18-2}

悪性貧血を合併した全身性エリテマトーデスの 1 例

○水野麗子 ${ }^{1}$, 藤本 隆 $^{1}$, 椎木英夫 ${ }^{1}$, 中村 忍 $^{2}$, 土肥和紘 ${ }^{1}$

( ${ }^{1}$ 奈良県立医科大学第 1 内科, ${ }^{2}$ 金沢大学医学部第 3 内科)

症例 : 71歳, 女性. 主訴 : 貧血. 家族歴 : 特記事項はない. 睌往歴 : 69歳右卵巣粘液 水腫（子宮全摘および附属器切除），クリプトコッカス症（肺炎および䯣膜炎）. 現病 歴 : 1993年に顔面紅斑，膝関節痛，抗核抗体・抗DNA抗体の陽性，および白血球・血小 板数の減少から，全身性エリテマトーデス（SLE）と診断された，以後には20〜 $5 \mathrm{mg} /$ 日 のプレドニン（PSL）が投与されていたが，1996年12月のクリプトコッカス症発症後か らは2.5 mg/日のPSLで維持されていた．1997年12月から貧血が徐々に進行し，1998年 4

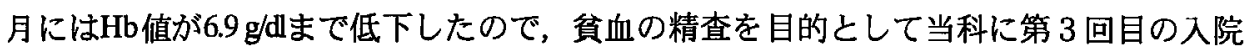
をした，身体所見：結膜に貧血と黄染を認める，左第 3 肋間胸骨左縁に最強点を有す るLevine $2 / \mathrm{VI}$ の収縮期駆出性雑音を聴取する. 入院時検査成績 : 大球性貧血（赤血球 194 万 $/ \mu 1, \quad \mathrm{Hb} 6.9 \mathrm{~g} / \mathrm{dl}, \mathrm{MCV} 104)$ に加えて間接ビリルピン值 $(1.6 \mathrm{mg} / \mathrm{dl})$ の上昇とVB12值

(173 pg/ml) の低下が認められた. クームステストは陰性であったが，抗内因子抗体は陽 性であった. 骨䯣像では, 赤芽球の過形成が雄認された. 入院後経過 : 悪性貧血と診断 してVB12の投与を開始し，Hb值は投与の 7 日後に10.4 g/dlまで改善した．結語：本例は， SLEに合併した悪性貧血であり，墨性貧血の成因を考えるのに興味深い. 


\title{
W 18-3
}

\author{
木村氏病の末梢血リンパ球の解析 \\ ○伯耆原祥, 上松一永, 小宮山淳 \\ （信州大・小肾科）
}

\begin{abstract}
木村氏病はリンパ滤胞の増生と好酸球浸潤を伴った炎症性肉芽腫が特徵で，末梢血好酸 球の増加，血清中 IgEの高值が認められる.【目的】木村氏病の病態を解明するために， 患者の末梢血 $\mathrm{T}$ 細胞, $\mathrm{B}$ 細胞機能について検討を行った.【方法】患者末梢血より単核球 を分離し, 羊赤血球ロゼット形成陽性細胞を用いて抗 CD3 mAb 刺激下におけるサイトカ イン（IL-4，IL-5，IFN- $\gamma$ )産生を健常人コントロールと比較した。また羊赤血球ロゼ ット形成陰性細胞から抗 CD19 mAb をコートした immunomagnetic beads を用いてB 細胞を精製し，IL-4+ 抗 CD40 mAb + CD32 transfectants の刺激下で 14 日間培盖し， 培養上清中の IgE ELISA で測定した. 未梢血単核球を IgD/CD27/CD20 抗体で染色 し、フローサイトメトリー法でB 細胞の population を解析した。【結果】健常人コント ロールに比較して患者末梢血 $\mathrm{T}$ 細胞は抗 $\mathrm{CD} 3 \mathrm{mAb}$ 刺激で著名な IL-4 と IL- 5 産生が認 められたが, IFN- $\gamma$ 産生は低下していた。 また患者末梢血 B 細胞の IgE抗体産生能は正 常であり,ナイーブ B 細胞とメモリーB 細胞の割合も正常であった.【結語】木村氏病に おける高 IgE 血症の原因が $\mathrm{T}$ 細胞側にあり，B 細胞は正常であることが示唆された.また T細胞は Th2 側のサイトカイン産生が六進しているために, 好酸球増多症や高 IgE 血症 が生ずるものと考えられた.
\end{abstract}

\section{W 18-4}

姡娠を契機に発症し H E L L P 症候群・血球貪食症候群を合併したS L Eの 1 例 ○田伏洋子，亀井宏治，横手耐治，鍵谷真希，林雅子，武内徹，岩尾㶳明， 槙野茂樹 (大阪医科大学第一内科)

症例は33藏女性。10年前より梅毒血清反応偽陽性、抗核抗体・抗リン脂翼抗体陽性であった が無症状にて放置。平成10年妊娠。7月1日 (妊娠23週) 高血圧、浮腫、蝶形紅班、手掌紅斑出現し入 院。検查にて抗 dSDNA杭体高值・抗リン脂質抗体陽性・補体低値を認め妊娠を合併したSLEと診 断、ステロイドバルス、血漿交換施行するも25週には高血圧が墨化、肺水腫、肝障害、警障害、血 小板減少が出現しHELLP症候群合併と考え帝王切開にて罚を婏出 (紧は380gで生後8日目に死亡)。産 後、瞥障害は增覀し無尿となり血液透析導入。ステロイドパルスを連日施行した上、血獎交換、工 ンドキサンパルスを毎週施行したところ霄機能回復し1月半後に透析を離脱し2月後には補体も正常 化した、しかし、血小板は回復せず骨䯙穿刺にて血球貝食像を認め、血球貪食症候群 (HPS) 合併と 判断、VP-16を投与し血小板減少は改善中である、また同時期にCMW網膜炎の合併も認めたが、gan cyclovirの投与にて軽快した。HELLP症候群は妊娠に伴ってみられる肝障害を伴う血小板隇少で、 その機序として血管内皮細胞障害が想定され、抗リン脂質抗体陽性例の報告もかなりあり本例も その範矒に入ると考える。また、HPSは膠原病、墨性リンパ腫、感染症に伴って見られ、本例では 途中で合併したCMV網膜炎の関連も考虑されたが、CMV網膜炎治瘾後も持続しておりやはりSLEに連 関したものと考えられる。本例は血小板減少を来たすHELLP症候群とHPSが同一症例に合併した興味 深い症例であり、最近 1 年間に当科で経験したHPSのまとめと併せて報告する。 


\section{W 18-5}

慢性 ITP の経過中に SLE を発症した小児 4 症例の検討

○高野容子、出口 靖、伊従秀章、斉藤義弘、小林尚明、藤沢康司 (東京慈恵会医科大学小児科)

【目的】自施設で経過観察中の慢性 ITP 患者の中に、新たに SLEを発症した 4 症例を経 験したのでまとめて報告し、その臨床像を比較検討する。

【症例】症例は 14 歳から 21 歳の男児 3 例、女児 1 例。いずれも小児期に慢性 ITP を発症 し当科で経過観察されていた。慢性 ITP 発症時には 1 例を除いて抗血小板膜抗体以外の自 己抗体の出現やSLEに特徵的な症状の合併はなかった。慢性 ITPの診断から 1-16年で SLE にみられる多臓器に渡る症状を合併し、同時に検査所見もSLEに合致するようになった。 治療経過は、ステロイド剤に良く反応し、血小板数を含めた症状・所見の改善を得られた。 【臨床像】各症例の慢性 ITP 診断年令及びSLE 発症までの罹病期間は、症例 1 が 8 ケ月時 診断 16 年後発症、症例 2 が 9 歳時診断 5 年後発症、症例 3 が 10 歳時診断 5 年後発症、症例 4 が 11 歳時診断 1 年後発症とまちまちであった。SLE としての初発症状は発熱が 2 例、関 節炎が 1 例、蝶形紅斑が 2 例、ネフローゼ症候群が 1 例で、全例初発時より腎障害を伴つ ていた。他の慢性 ITP と比べ、初発時より抗血小板膜特異抗体が異常に高い傾向があった。

【結語】SLEが経過中に他の自己免疫疾患とオーバーラップすることは知られているが、 小肾期の良性疾患として知られるITP の中にも長い年月を経て全身性の免疫疾患に移行し ていくものがあり、注意深い経過観察が必要である。 